\title{
Role of The ICT in Women Empowerment and Achieving SDGs: A Case Study of Women Labor Force in Developing Countries
}

\author{
Amna Noor', Zahid Asghar ${ }^{2}$, Haroon Sarwar', M. Irfanullah Arfeen ${ }^{4 *}$ \\ 1,2School of Economics, Quaid-i-Azam University, Pakistan \\ ${ }^{3}$ Federal Ministry of Planning, Development and Reforms, Pakistan \\ ${ }^{4}$ School of Management Sciences (QASMS), Quaid-i-Azam University, Pakistan \\ E-mail: 'nooramnaasim@gmail.com, 2zasghar@qau.edu.pk, \\ ${ }^{3}$ hsa666@hotmail.com, ${ }^{4}$ m.arfeen@qau.edu.pk
}

${ }^{*}$ Corresponding Author

\section{JEL Classification: \\ $\mathrm{J} 21$ \\ I25 \\ Q01}

Received: 09 August 2021

Revised: 06 September 2021

Accepted: 30 September 2021

\begin{abstract}
This study aims to analyze the ways women are empowered through Information and Communication Technology (ICT) and fostering the process of achieving the Sustainable Development Goals (SDGs). Women in developing countries face economic and social hurdles and have limited access to ICT, which transforms into their lack of skills, lower literacy rate, and limited social engagement. Therefore, this study explores the role of ICT on women empowerment in 51 developing countries by conducting panel data modeling throughout 2000-17. The study finds that ICT has a positive contribution to the female labor force participation rate by applying the Generalized Method of Moment (GMM). Control variables like GDP growth and government expenditure on education have a positive and statistically significant role in enhancing women's empowerment. The findings of this study explain that the ICT impacts women's empowerment and returns, beneficial for fostering the process of achieving SDGs 2030 .
\end{abstract}

Keywords:

women, developing countries, empowerment, education, female labor force

\section{How to Cite:}

Noor, A., Asghar, Z., Sarwar, H., \& Arfeen, M. I. (2021). Role of the ICT in Women Empowerment and Achieving SDGs: A Case Study of Women Labor Force in Developing Countries. Etikonomi, 20(2), 339 - 348. https://doi. org/10.15408/etk.v20i2.22045. 


\section{Introduction}

Information and Communication Technology (ICT) have been recognized as an essential indicator for women's empowerment. There is no exact and universal definition of ICT. It includes all devices, networking components, applications, and systems that allow individuals and institutions to act efficiently in the digital world like cell phones and the Internet. ICT access through mobile phones and broadband has increased more rapidly than those of other technologies. Broadband subscribers increased more than double in eight years, it was 527 million in 2010, and in 2018 it became 1.1 billion (GDR 2019). Internet users worldwide have increased up to three-fold in the last few years, from 1 billion users in 2005 to 3.2 billion users in 2015 (ITU 2017). According to the latest Global Digital Report, the Internet users are 4.39 billion, while cell phone users are 5.11 billion (GDR 2019). It has been found that 1.3 billion Internet users are women $(37 \%$ in the whole world are using the Internet), while 1.5 billion men online ( $41 \%$ of all men), which correspond to 200 million fewer women online (World Bank, 2016).

The United Nations member states in 2015 agreed on the agenda named Sustainable Development Goals (SDGs) 2030 (UN 2015), which includes 17 goals, and each goal comprises several targets and indicators. International organizations (United Nations and World Bank) promote ICT to empower women, and ICT is also a primary attribute of the SDGs 2030. The easy and quick access of ICT for women can facilitate and accelerate the achievement of the SDGs. Women's use of ICT is significantly lagging behind men's in the developing world (Perryman \& Arcos 2016). Therefore, gender inequality is a pressing policy concern in the SDGs agenda (Asongu \& Odhiambo 2018). It is essential to understand that for the development of a nation, steps should be taken to empower women.

The way ICT has transformed our lives over the last two decades has been effectively captured by the global literature. ICT-related research has given birth to a whole stream of theoretical and inter-disciplinary empirical research. A significant part of this literature has tried to assess the economic impact of ICT on women's empowerment as well. The ICT's definition and scope have attained different dimensions in the literature. It is like Information Technology (IT), but its main concern is on communication technologies. ICT is confined to the use of the computer, the Internet, cell phones, and telephone lines, but it is also about information and communication (Dlodlo, 2009). Herman (2020) concludes that there is a strong positive correlation between the economy's digitalization level and labor productivity.

World Bank explains the ICT as the combination of hardware, software, networks, and media for assemblage, storage, processing program, and demonstration of information in the form of voice, data, text, and description (World Bank, 2016). The ICT provides people with access to and sharing information that can increase their capabilities and lead them to empower (Obayelu \& Ogunlade, 2006). According to (Mansell \& Wehn 1998), effective use of ICT can develop and empower societies through greater inclusion, 
wellbeing, cooperation, and participation. ICT affects the quality of life through knowledge, education, and skills. Similar to ICT, there is no worldwide definition of 'empowerment. Many empirical studies are based on measuring ICTs impact on female participation in the labor market and showed that an increase in the use of ICT would, in turn, increase the participation of females in the labor force (Chen, 2004; Efobi et al., 2018; Nikulin, 2017; Shehata, 2017). Easy access and the use of ICT positively impact closing the gender employment gap, as ICT tends to provide employment opportunities for women (Shehata, 2017).

ICT is one of the fastest ways for empowering historically disadvantaged groups, such as women and minorities (Hafkin \& Huyer, 2006). ICT gives empowerment by giving access to complete information, excellence, and reliability of such information that helps make decisions (Ogato, 2013). Thus, ICT empowers women by increasing their purchasing power, making decisions, and controlling issues that improve their lives.

Globally, the number of women accessing ICTs and ICT devices is $12 \%$ lower than men (ITU, 2017). According to the ITU, Internet access costs about $11 \%$ to $30 \%$ of the average monthly income in developing countries, with more than half of the monthly income in developed countries (ITU, 2017). The World Wide Web Foundation (WWWF) has revealed that these high costs have limited women's access to ICT, information, and knowledge, increasing their exposure to the global digital economy. This condition has made access to ICT a challenge for many families, especially for women who face more gender discrimination. Developing countries suffer from many economic and social crises that they cannot provide ICT services to disadvantaged people or rural communities. Even within a country, there exist inequalities among urban and rural populations in accessing ICT.

In our study, we take empowerment as a process that makes women recognize themselves for accomplished tasks and lead them to make decisions about their lives in economic, social, and cultural aspects. The study's main objective is to determine the role of ICT in enhancing women's empowerment and to help in fostering the process of achieving SDGs 2030. The study seeks to identify and further understand the possible ICT indicators and process of indices formation. The study conducts an in-depth quantitative and qualitative analysis to evaluate the effectiveness of ICT on female labor force participation and women's empowerment.

The study's research question is, to what extent does ICT play a role in the equation of women's empowerment and economic development in developing countries? The study contributes to the existing literature by examining the role of ICT on women's empowerment by focusing on Goal 5 (Gender Equality and Empower all Women and Girls) and target $5 \mathrm{~b}$ specifically focus on enhancing the use of technology to empower women. Also, find to what extent technology plays a role in the equation of economic development and women's empowerment in developing countries. Therefore, this study aims to identify the role of ICT in women's empowerment for fostering SDGs and provide policy relevance to foster the process of achieving the SDGs 2030. 


\section{Methods}

In this section, we will discuss the source of data and define the variables. This study uses World Development Indicators (WDI) of the World Bank for ICT indicators and control variables. The study analyzes the panel data of 51 developing countries for the period 2000-17. The study constructs an ICT index from several ICT indicators. The study uses the following indicators to develop the ICT index, mobile phone users per 100 people, internet users per 100 people, fixed broadband subscribers per 100 people, and telephone users per 100 people. The study used the weighted average method to convert the ICT indicators into a composite index. We also use different control variables in order to avoid the problem of omitted variable bias. Table 1 presents the detailed definition of all variables.

Table 1. Definition of Variables

\begin{tabular}{|c|c|c|c|}
\hline Variables & Symbols & Source & Description \\
\hline \multicolumn{4}{|l|}{ Dependent Variables } \\
\hline $\begin{array}{l}\text { Female labor force } \\
\text { participation }\end{array}$ & FLFP & WDI & $\begin{array}{l}\text { Labor force participation rate of female from the } \\
\text { total working population of age } 15-64 \text {. It is a proxy } \\
\text { used for measuring women's empowerment taken. }\end{array}$ \\
\hline \multicolumn{4}{|l|}{ Main variable of interest } \\
\hline ICT index & ICT Index & WDI & $\begin{array}{l}\text { It is a main independent variable and also an } \\
\text { important indicator of SDG goal } 5(5 \mathrm{~b}) \text {. } \\
\text { i) the Internet users per } 100 \text { person who have } \\
\text { access the worldwide networking, } \\
\text { ii) mobile phone users per } 100 \text { person, } \\
\text { iii) telephone main line users per } 100 \text { person by } \\
\text { connecting a customer's equipment to the } \\
\text { public network } \\
\text { iv) the fixed broadband subscribers per } 100 \\
\text { person. }\end{array}$ \\
\hline \multicolumn{4}{|l|}{ Control Variables } \\
\hline GDP & GDP & WDI & $\begin{array}{l}\text { It is an indicator of SDG goal } 8 \text { (Decent work and } \\
\text { economic growth) GDP per capita is taken as the } \\
\text { proxy for economic development. }\end{array}$ \\
\hline $\begin{array}{l}\text { Gross fixed capital } \\
\text { formation }\end{array}$ & GFCF & WDI & $\begin{array}{l}\text { Gross fixed capital formation is taken as annual } \\
\text { growth rate of investment. }\end{array}$ \\
\hline Fertility rate & $\mathrm{FR}$ & WDI & Fertility rate total birth per women. \\
\hline Urban ratio & UR & WDI & Urban Population divided by total Population. \\
\hline $\begin{array}{l}\text { Government consumption } \\
\text { expenditure }\end{array}$ & GCE & WDI & $\begin{array}{l}\text { General government final consumption expenditure } \\
\text { (annual growth rate). }\end{array}$ \\
\hline $\begin{array}{l}\text { Government expenditure } \\
\text { on education }\end{array}$ & GEE & $\begin{array}{l}\text { WDI } \\
\text { SDG }\end{array}$ & $\begin{array}{l}\text { GEE is the financial variable from SDG goal } 4 \\
\text { focus on indicator } 4.5 .4 \text { and } 4.5 .5 \text {. Government } \\
\text { expenditure on education (annual growth rate). }\end{array}$ \\
\hline Trade openness & TO & WDI & Import plus export divided by GDP. \\
\hline
\end{tabular}


The previous studies have used different econometric techniques like OLS, GLS, IV, ARDL, and GMM techniques to investigate the impact of ICT on women empowerment (Chen, 2004; Islam, 2015; Nikulin, 2015; Efobi et al., 2018; Asongu \& Odhiambo, 2018). In the present study, we are using the GMM approach (Asongu \& Odhiambo, 2018). The reason for adopting GMM is that it produces more efficient estimates, avoids the proliferation of instruments, and tackles the issues of endogeneity, heterogeneity, and over-identification.

In this study, the female labor force participation rate has been used as a dependent variable, while the ICT index is our primary independent variable supported by several control variables. Hence the model is provided below.

$$
\begin{aligned}
F L F P_{i t}= & \beta_{1}+\beta_{2} F L F P_{i t-1}+\beta_{3} G D P_{i t}+\beta_{4} I C T_{i t}+\beta_{5} F R_{i t}+\beta_{6} U R_{i t}+ \\
& \beta_{7} l n T O_{i t}+\beta_{8} \ln G F C F_{i t}+\beta_{9} g C e_{i t}+\beta_{10} g e e_{i t}+\varepsilon_{i}+\eta_{t}+\mu_{i t} \\
F L F P_{i t}- & F L F P_{i t-1}=\beta_{2}\left(F L F P_{i t-1}-F L F P_{i t-2}\right)+\beta_{3}\left(G D P_{i t}-G D P_{i t-1}\right)+ \\
& \beta_{4}\left(I C T_{i t}-I C T_{i t-1}\right)+\beta_{5}\left(F R_{i t}-F R_{i t-1}\right)+\beta_{6}\left(U R_{i t}-U R_{i t-1}\right)+ \\
& \left.\beta_{7} \ln T O-\ln T O_{i t-1}\right)+\beta_{8}\left(\ln G F C F_{i t}-\ln G F C F_{i t-1}\right)+\beta_{9}\left(g c e_{i t}-\right. \\
& \left.g c e_{i t-1}\right)+\beta_{10}\left(g e e_{i t}-g e e_{i t-1}\right)+\left(\eta_{t}-\eta_{t-1}\right)+\left(\mu_{i t}-\mu_{i t-1}\right)
\end{aligned}
$$

Where $\varepsilon_{i}$ is the country-specific effect, while $\eta_{t}$ time-specific constant and $\mu_{i t}$ is the residual of the model.

The current analysis is based on the GMM approach. Our purpose of using two differenced GMM is to take care of the following issue. Firstly, the number of crosssections is greater than the number of time series, i.e., $N>T, 51>18$. Secondly, to handle the endogeneity problem for time-invariant omitted variables and simultaneity handled by taking instruments that also control heterogeneity. Thirdly, there should be panel data for the GMM method, which shows that cross-country differences are considered (Asongu \& Nwachukwu, 2017; Efobi et al., 2018). Fourthly, the female labor force participation with lag value is consistent over time as the correlation coefficient between the level and first lag of the indicators is higher than 0.8 (Asongu \& Odhiambo 2018).

The United Nations says the need for ICTs is the third most important problem facing women worldwide, after poverty and violence against women. ICTs can influence the gender discrimination found in many areas of development, such as education, health care, and access to economic opportunities (UN Women 2020). Many international organizations now support projects in developing parts of the world and introduce new ICTs to aid social and economic development (United Nations 2009).

Advances in ICT have brought new opportunities for information sharing and information collection for women and men. ICT offers unlimited opportunities for economic development and social engagement through innovative thinking and innovative tools. If access to and use of ICT is directly linked to social and economic development, it is crucial to ensure that women in developing countries understand the importance and use of this technology. ICT can be used as a tool for women's empowerment, leading to equality and economic stability. Without the inclusion of ICT in the information age, countries are less likely to develop. 
It is widely distributed that ICT enables the inclusion of low-skilled and traditionally marginalized groups, such as women, people with disabilities, and workers, as the basis of the pyramid in the labor market. Therefore, ICT empowers women, and this empowerment focuses on the importance of developing their capacity and controlling the decisions and issues that shape their lives.

\section{Result and Discussion}

Table 2 shows the descriptive statistics of the given variables. Summary statistics show that almost $46 \%$ of the women in the given countries participate in the labor force. While across countries, variation in the labor force is $15 \%$. As provided in Table 2 , the average value of the ICT index in developing countries is very low (25.81), and across the country, variation is $17 \%$.

Table 2. Descriptive Statistics

\begin{tabular}{cccccc}
\hline Variable & Obs. & Mean & Std. Dev. & Min & Max \\
\hline Flfpr & 918 & 45.82 & 15.044 & 11.893 & 81.841 \\
ICT & 918 & 25.81 & 17.526 & 0.167 & 70.966 \\
GDP & 918 & 4.344 & 3.368 & -14.759 & 18.287 \\
Fr & 918 & 2.622 & 0.975 & 1.085 & 5.58 \\
Ur & 918 & 0.552 & 0.194 & 0.182 & 0.988 \\
Gfff & 918 & 6.027 & 13.15 & -41 & 57.964 \\
Gce & 918 & 4.395 & 6.643 & -23.076 & 85.359 \\
Gee & 918 & 4.394 & 2.023 & 1.012 & 14.059 \\
Trade & 918 & 0.742 & 0.354 & 0.156 & 2.473 \\
\hline
\end{tabular}

Table 3 provides the correlation matrix for all variables that are used in estimation. It has been observed from the Table that the ICT index has a positive association with the outcome variable. Also, the ICT index has a significant association with other control variables, and there is no multicollinearity observed among variables.

Table 3. Correlation Matrix:

\begin{tabular}{|c|c|c|c|c|c|c|c|c|c|}
\hline Variables & 1 & 2 & 3 & 4 & 5 & 6 & 7 & 8 & 9 \\
\hline Flfpr & 1 & & & & & & & & \\
\hline ICT & 0.047 & 1 & & & & & & & \\
\hline GDP & 0.073 & -0.238 & 1 & & & & & & \\
\hline $\mathrm{Fr}$ & 0.032 & -0.445 & 0.036 & 1 & & & & & \\
\hline Ur & -0.044 & 0.423 & -0.218 & -0.464 & 1 & & & & \\
\hline Gfcf & -0.014 & -0.131 & 0.407 & -0.01 & -0.033 & 1 & & & \\
\hline Gce & 0.082 & -0.137 & 0.238 & 0.159 & -0.179 & 0.036 & 1 & & \\
\hline Gee & 0.09 & 0.119 & -0.148 & -0.135 & 0.187 & -0.077 & -0.147 & 1 & \\
\hline Trade & 0.276 & 0.214 & 0.017 & -0.183 & -0.027 & -0.007 & -0.015 & 0.241 & 1 \\
\hline
\end{tabular}


To ensure the robustness of our results, we have estimated three models by including a set of additional variables to find that our results are consistent. The ICT index is statistically significant. The ICT has a positive impact on FLFP and can strengthen the efforts for achieving SDG 5. The result shows that if 1 unit increases the ICT index, the female labor force participation rate will increase by 0.037 percent. Although this result shows lower influence than other indicators, all three models suggest that the ICT positively impacts women's empowerment and helps foster the process of SDGs 2030.

Table 4. Dependent Variable: Female Labor Force Participation Rate

\begin{tabular}{cccc}
\hline & $(1)$ & $(2)$ & $(3)$ \\
\hline L.ffpr & $0.371^{* * *}$ & $0.336^{* * *}$ & $0.415^{* * *}$ \\
& $(11.44)$ & $(8.73)$ & $(16.77)$ \\
ICT & $0.0314^{* * *}$ & $0.0418^{* * *}$ & $0.0373^{* * *}$ \\
& $(3.71)$ & $(5.26)$ & $(4.57)$ \\
GDP & $0.028^{* *}$ & $0.0344^{* * *}$ & $0.0516^{* * *}$ \\
& $(3.12)$ & $(3.83)$ & $(11.96)$ \\
fr & -0.142 & & \\
& $(-0.32)$ & & $-0.0554^{* * *}$ \\
gce & $-0.0568^{* * *}$ & $-0.0621^{* * *}$ & $(-4.57)$ \\
& $(-7.28)$ & $(-7.40)$ & $-1.977^{* * *}$ \\
InTO & $-2.194^{* * *}$ & $-2.486^{* * *}$ & $(-6.40)$ \\
& $(-6.52)$ & $(-7.32)$ & $-14.12^{* *}$ \\
ur & -4.186 & $-10.28^{*}$ & $(-2.81)$ \\
& $(-0.56)$ & $(-2.58)$ & \\
Ingfcf & $0.061^{*}$ & 0.0425 & $0.719^{* * *}$ \\
& $(2.41)$ & $(1.47)$ & $(8.46)$ \\
gee & $0.467^{* * *}$ & $0.573^{* * *}$ & 816 \\
& $(4.05)$ & $(6.09)$ & 0.001 \\
$\mathrm{~N}$ & 816 & 816 & 0.392 \\
AR(1) & 0.018 & 0.037 & \\
AR(2) & 0.674 & 0.587 & \\
\hline
\end{tabular}

Table 4 shows the expected signs of control variables; the GDP growth has a positive and significant impact on women's empowerment. The results indicate that economic development is inclusive concerning women's empowerment in developing countries. The government expenditure on education has a positive impact on FLFP, and it helps foster the process of SDGs regarding goal 4. GFCF has a positive association with women's empowerment, which shows that investment positively impacts women's empowerment.

On the other hand, trade openness has a significant but negative impact on FLFP, that is, in the case of developing countries. Firstly, trade openness leads to an increase in capital accumulation that raises per capita GDP, and this increasing income discourages female participation. Secondly, more import means less domestic economic activities that in turn imply lower FLFP. Thirdly, it increased the demand for skilled labor, which caused fewer job offers for females (Wood 1998). Our estimates suggest that, on average, a 1 percent rise in the government final consumption expenditure is associated with 
about a 0.057 percent reduction in women empowerment in developing countries due to low earn income of women in developing countries and dependency ratio high. In the case of developing countries, the urban ratio has a negative impact on FLFP. The reason could be that women focus on more education attainment, and in urban areas, mostly work required factories rather than at home, which causes a reduction in female participation in the labor market (Mitra, 2019).

Women's empowerment is driven by their living standards and increasing educational attainment and opportunities created in modern countries (Klasen \& Pieters 2012). ICT is knowledge-based, and many aspects influence its entry into the labor market, and education is one of the most vital factors in determining access to its labor market. Involvement of the ICT with the support of educational needs helps empower women in society (Chen, 2004; Aydin, 2021).

Many studies have emphasized women's empowerment through ICT, such as education, knowledge formation, and employment (Hafkin, 2000; Chen 2004; Islam 2015). The ICT can improve women's social and economic conditions in developing countries (Asongu \& Odhiambo, 2018; Tam et al., 2020; Ngoa \& Song, 2021). Several reports have discussed opportunities for women's empowerment through ICT, e.g., through education and knowledge building, poverty alleviation, and job creation (Hafkin, 2000; Samargandi et al., 2019). The most important determinant of a country's competitiveness is its human strength and talent, skills, education, and productivity. Women write for half the available talent. Closing gender gaps is therefore not just a matter of human rights and equality but also economic productivity. ICT utilization plays an essential role in middle-aged and older females (Kuo et al., 2013).

\section{Conclusion}

As having almost an equal proportion in terms of population, it is necessary to highlight the issues to provide suitable solutions for women as for men so that both can contribute towards economic betterment. The ICT has played an essential role in empowering women over the past couple of decades and has a distinctive consideration in the setting of SDGs. This study finds that the ICT positively impacts women's empowerment, which shows that easy access and use of the ICT can improve the female labor force participation rate. Another feature variable like GDP growth rate, government expenditure on education, and gross fixed capital formation also positively impacts women empowerment.

Our finding supports the positive role of the ICT on female labor force participation rate, which implies the SDGs goal 5, in many perspectives notably, empowering women, enhancing technology, increasing participation of women in the labor force, inclusive development, and economic growth in developing countries. It is necessary to make women feel empowered and an essential part of society to participate in economic activities. There is a need to feel women motivated enough to lead them to achieve self-actualization, increase their productivity, and foster achieving SDGs 2030 through 
ICT. Therefore, it is beneficial for any society to empower women, and ICT is one of the crucial tools to achieve this objective.

\section{References}

Asongu, S., \& Nwachukwu, J, C. (2017). Mobile phone in Diffusion of knowledge and Persistence in Inclusive Human Development in Sub-Saharan Africa. Journal of Information Development, 33(3), 289-302. https://doi.org/10.1177/0266666916655189.

Asongu, S., \& Odhiambo, N. M. (2018). ICT, Financial Access and Gender Inclusion in the Formal Economic Sector. African Finance Journal, 22(2), 45-65.

Aydin, M. (2021). Does The Digital Divide Matter? Factors and Conditions That Promote ICT Literacy. Telematics and Informatics, 58, 101536. https://doi.org/10.1016/j. tele. 2020.101536.

Chen, D. H. C. (2004). Gender Equality and Economic Development: The Role for Information and Communication Technologies. World Bank Policy Research Working Paper Series 3285. https://doi.org/10.1596/1813-9450-3285.

Dlodlo, N. (2009). Access to ICT Education for Girls and Women in Rural South Africa: A Case Study. Technology in Society. 31(2), 168-175. https://doi.org/10.1016/ jtechsoc. 2009.03.003.

Efobi U. R., Tanankem B. V., \& Asongu S. (2018). Female Economic Participation with Information and Communication Technology Advancement: Evidence from Sub-Saharan Africa. South African Journal of Economics, 86(2), 231-246.

Hafkin, N. (2000). Convergence of Concepts: Gender and ICT in Africa. In: Rathgeber, E. M., \& Adera, E. O. (eds). Gender and The Information Revolution in Africa, 1-18. International Development Research Centre. Canada.

Hafkin, N., \& Huyer, S. (2006). Cinderella or Cyberella? Empowering Women in The Knowledge Society. Kumarian Press. Bloomeld, CT.

Herman, E. (2020). The Influence of ICT Sector on the Romanian Labour Market in the European Context. Procedia Manufacturing, 46, 344-351. https://doi.org/10.1016/ j.promfg.2020.03.050.

Islam, M. S. (2015). Impact of ICT on Women Empowerment in South Asia. Journal of Economic and Financial Studies, 3(3), 80-90.

ITU. (2017). World Telecommunication Development Report. ITU. Geneva, Switzerland

Klasen, S., \& Pieters, J. (2012). Push or Pull? Drivers of Female Labor Force Participation During India's Economic Boom. IZA Discussion Paper No. 6395.

Kuo, F-Y., Tseng, F-C., Lin, C. I. C., \& Tang, W-H. (2013). Critical Success Factors for Motivating and Sustaining Women's ICT Learning. Computers \& Education, 67, 208-218. https://doi.org/10.1016/j.compedu.2013.03.006.

Mansell, R., \& When, U. (1998). Knowledge Societies: Information Technology for Sustainable Development. Oxford University. Oxford. 
Mitra, A. (2019). Women Work in Response to Urbanization: Evidence from Odisha. ANTYAJAA: Indian Journal of Women and Social Change, 4(1), 92-106.

Ngoa, G. B. N., \& Song, J. S. (2021). Female Participation in African Labor Markets: The Role of Information and Communication Technologies. Telecommunications Policy, 45(9), 102174. https://doi.org/10.1016/j.telpol.2021.102174.

Nikulin, D. (2017). The Impact of ICTs on Women's Economic Empowerment. In: Kaur, H., Lehman, E., \& Marszk, A. (eds). Catalyzing Development Through ICT Adoption, 15-24. Springer. Cham.

Obayelu, A. \& Ogunlade, I. (2006). Analysis of the Uses of Information Communication Technology (ICT) for Gender Empowerment and Sustainable Poverty Alleviation in Nigeria. International Journal of Education and Development, 2(3), 45-69.

Ogato G S (2013). The Quest for Gender Responsive Information Communication Technologies (ICTs) Policy in Least Developed Countries: Policy and Strategy Implications for Promoting Gender Equality and Women's Empowerment in Ethiopia. International Journal of Information Technology and Business Management, 15(1), 23-44

Perryman, L. A., \& Arcos, B. L., (2016). Women Empowerment Through Openness: OER, OEP and The Sustainable Development Goals. Open Praxis, 8(2), 163-180. https://doi.org/10.5944/openpraxis.8.2.289.

Samargandi, N., Al Mamun, Md., Sohag, K., \& Alandejani, M. (2019). Women at Work in Saudi Arabia: Impact of ICT Diffusion and Financial Development. Technology in Society, 59, 101187. https://doi.org/10.1016/j.techsoc.2019.101187.

Shehata A. M. H., (2017). Role of Information and Communication Technology in closing Gender Employment Gap in MENA Countries. The Business and Management Review, 8(4), 168-178.

Tam, H-L., Chan, A. Y-F., \& Lai, O. L-H. (2020). Gender Stereotyping and STEM Education: Girls' Empowerment Through Effective ICT Training in Hong Kong. Children and Youth Services Review, 119, 105624. https://doi.org/10.1016/j. childyouth. 2020.105624.

Wood, A. (1998). Globalization and Rise in the Labour Market Inequalities. The Economic Journal, 108(450), 1463-1482.

World Bank. (2016). Digital Dividends, World Development Report 2016. World Bank. Washington DC 